ДАРЕНСЬКИЙ О.М., д-р техн. наук, професор, МАЛІШЕВСЬКА А.С., аспірант (Український державний університет залізничного транспорту)

\title{
Використання математичної моделі динамічної системи «екіпаж- колія» для досліджень сил взаємодії рухомого складу та колії метрополітенів
}

У статті проведено визначення вертикальних та горизонтальних поперечних динамічних сил, які виникають при взаємодії рухомого складу і колій метрополітену. Визначення здійснювалось на основі попередніх досліджень, в результаті яких були розроблені моделі та методи розрахунків таких сил. У статті наведена реалізація математичних моделей за допомогою програми Маtсаd. Новизна підходу дослідження при взаємодї рухомого складу $i$ колій метрополітену полягає в урахуванні та оцінюванні рівня саме горизонтальних поперечних сил .

Ключові слова: вертикальні сили, горизонтальні поперечні сили, колія, нерівнопружність рейкових опор, коефіцієнт динаміки, вертикальна ізольована нерівність.

\begin{tabular}{l}
\hline Вступ \\
\hline Назвати обгрунтовані рекомендації щодо \\
підвищення ресурсів роботи елементів колій \\
метрополітенів, насамперед найбільш коштовних \\
елементів - рейок, можна тільки на основі інформації \\
про вертикальні та горизонтальні поперечні сили, які \\
виникають в таких умовах. \\
Слід зазначити, що у фаховій та спеціальній \\
літературі практично немає інформації про рівень \\
таких сил та залежності іх зміни протягом часу. \\
Ситуація погіршуєтья тим, що виконання \\
експериментальних робіт в тунелях метрополітену при \\
робочому русі потягів практично неможливе. Одним із \\
способів вирішення цієї проблеми є числові \\
дослідження таких сил, які проводяться на
\end{tabular}
комп'ютерній техніці.

\section{Об'скт дослідження та його технологічний аудит}

Для оцінки рівня сил, що діють на рейки від рухомого складу, для обраних дослідних ділянок колій КП «Харківський метрополітен» були проведені багатоваріантні розрахунки.

Як розрахункові було прийнято такі типи рухомого складу метрополітену:

Холодногірська лінія - вагони типів Еж3, Ем-508Т;

Салтівська лінія - вагони типів 81-717, 81-714;

Олексіївська лінія - вагони типів 81-718, 81-719.

Швидкість руху прийнятих до розрахунку екіпажів змінювалась в межах до 80 км/год.

() О. М. Даренський, А. С. Малішевська, 2017
Для кожного типу екіпажу враховувалось 25 параметрів. Загально-розрахункова схема ділянки колії наведена на рис. 1. Довжина прямої ділянки задавалась в межах від 100 до 150 м, кругової кривої - 50-100 м, довжина перехідних кривих та підвищення зовнішньої рейки в кругових кривих приймалось за діючими нормами, відповідно до [18], таким чином, загальна розрахункова довжина ділянки колії складає, як правило, від 250 до 400 м.

Як змінні в розрахунках приймались такі параметри колії:

- радіуси кругових кривих від 200 до 600 м;

- довжина вертикальних нерівностей від 2 до $25 \mathrm{M}$

- глибина вертикальних нерівностей від 0,05 до $0,010 \mathrm{M}$;

- довжина горизонтальних нерівностей від 1 до 8 м;

- стріла вигину горизонтальних нерівностей від 0,03 до 0,09 м;

- $\quad$ термін експлуатації коліїі від 0 до 15 років.

Місце розміщення вертикальних і горизонтальних нерівностей по довжині розрахункової дільниці змінювалось та розглядались варіанти, при яких нерівності знаходились в прямій перехідній та круговій кривій.

Просторові жорсткості та приведені еквівалентні дисипації рейкових опор приймались в залежності від термінів експлуатації колії.

В розрахунках був прийнятий тип рейок Р-50, оскільки такий тип $\epsilon$ основним для колії метрополітену. Але характеристики рейок цього типу та моменти інерції, моменти оперу та площі 
поперечного перетину приймались різними в залежності від зносу рейок, прийняті в розрахунках значення - 3 урахуванням досліджень зносу рейок. Таким чином, були виконані розрахунки більш ніж 100 варіантів взаємодії різних вагонів і колій з різними характеристиками. Далі надається загальний аналіз залежності змін вертикальних та горизонтальних поперечних сил дії на колію вагонів метро в залежності в основному від експлуатаційних параметрів колії метрополітену.

\section{Мета та задачі дослідження}

Метою даної роботи є визначення вертикальних та горизонтальних поперечних динамічних сил, що виникають в умовах колії метро, із застосуванням моделі і методів розрахунків таких сил, які наведені в [16], ці математичні моделі були реалізовані в Matcad.

Мета роботи обумовила вирішення таких задач:

1. Визначення вертикальних сил взаємодії різних типів рухомих складів та колії, встановлення впливу швидкості руху та термінів служби колії, встановлення впливу вертикальних ізольованих нерівностей на ці сили, впливу довжини нерівності та їх амплітуди.

2. Проведення розрахунків горизонтальних поперечних сил в прямих та кривих ділянках колій метро.

3. Встановлення швидкості руху параметрів рейкової колії 1 в на ці сили. Встановлення впливу горизонтальних нерівностей колії та параметрів цих нерівностей на величину горизонтальних поперечних сил.
Аналіз літературних даних та постановка задачі

Питання динаміки взаємодії рухомого складу i колії для умов магістральних залізниць і колій незагального користування розглядались в роботах [1], [2], [3], [4], [5], [6], [7-11] ті ін. Але робота колій метро не розглядалась. В роботі [12] надані характеристики верхньої будови колії, яка застосовується в умовах метро СНД, надані параметри вертикального модуля пружності колії метро та характеристик жорсткості рейкових ниток під дією горизонтальних поперечних сил. Рівень вертикальних та горизонтальних поперечних сил взаємодії рухомого складу та колії не визначався. В роботі [13-17] досліджувався рівень вертикальних динамічних сил на рівні 90-92 кН.

\section{Матеріали та методи дослідження}

Геометричні параметри рейкової колії:

- відстань від початку кривої (довжина) до прямої ділянки колії $l_{H \kappa}, \mu$;

- довжина перехідної кривої $l_{\Pi \kappa}, м$;

- довжина кругової кривої $l_{K \kappa}, \mu$;

- загальна довжина розрахункового відрізка колії $l_{H K}+l_{\Pi K}+l_{K K}, \mu$

- підвищення зовнішньої рейки в круговій кривій $h_{K K}, \mu$.

Вертикальна нерівність колії характеризується такими параметрами:

- відстані до початку нерівності $l_{\text {начz }}, \mu$;

- довжина нерівності $l_{\text {нерz }}, \boldsymbol{M}$.

Горизонтальна нерівність колії у свою чергу має такі параметри:

- відстань до початку нерівності $l_{\text {начу }}, \boldsymbol{M}$;

- довжина нерівності $l_{\text {неру }}, м$.
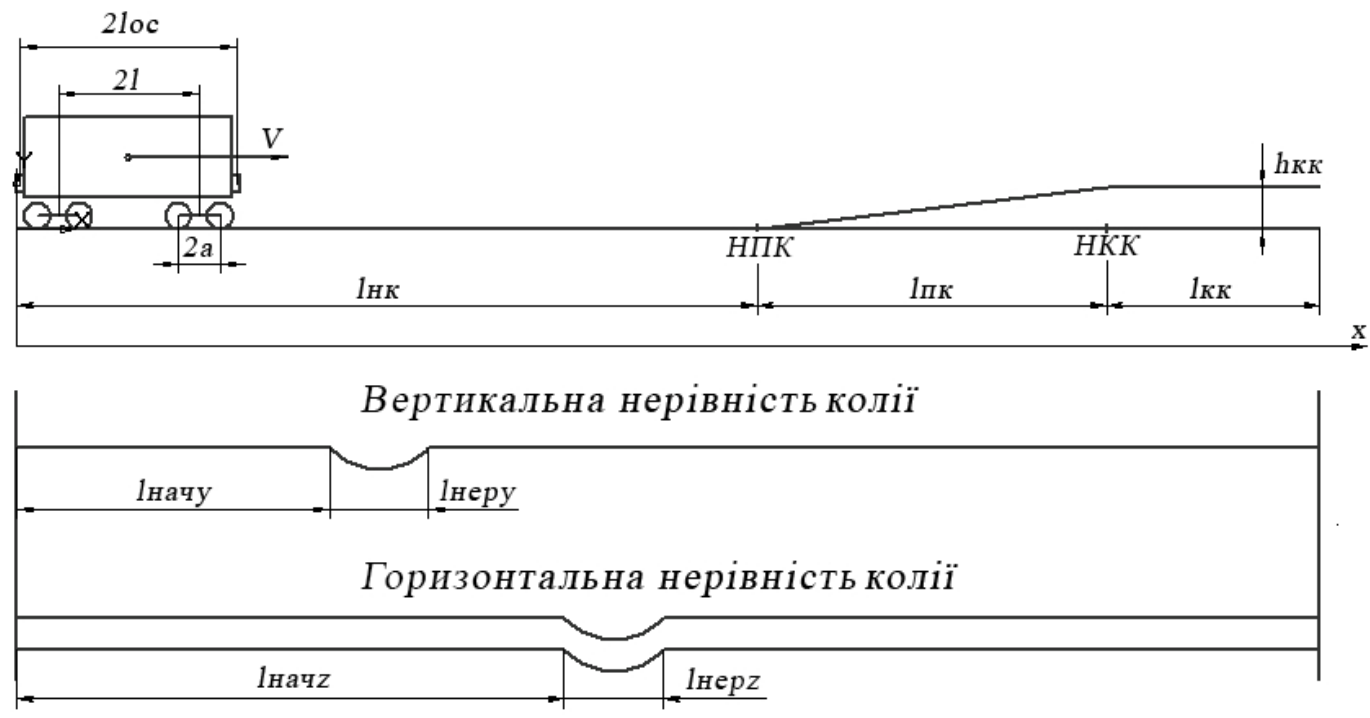

Рис. 1. Розрахункова схема ділянки колії 
Вертикальні сили. Оскільки вертикальні сили дії на колію вагонів метрополітену залежать не тільки від їх типу та безперервно змінюються при русі екіпажів, для порівняльного аналізу більш зручно та інформативно використовувати не їх абсолютні значення, а коефіцієнти динаміки i амплітудні коефіцієнти. Коефіцієнт динаміки - це відношення максимальних вертикальних динамічних сил, які виникають при русі, до величини статичного колісного навантаження
$K \partial=\frac{P \max }{P c m}$.

Оскільки при русі вагонів вертикальні сили змінюються не тільки в більший, а і в менший від статистичних значень бік, величину цих змін можна оцінювати значеннями амплітудного коефіцієнта

$K a=\frac{P \max \partial u H}{P \min \partial u H}$

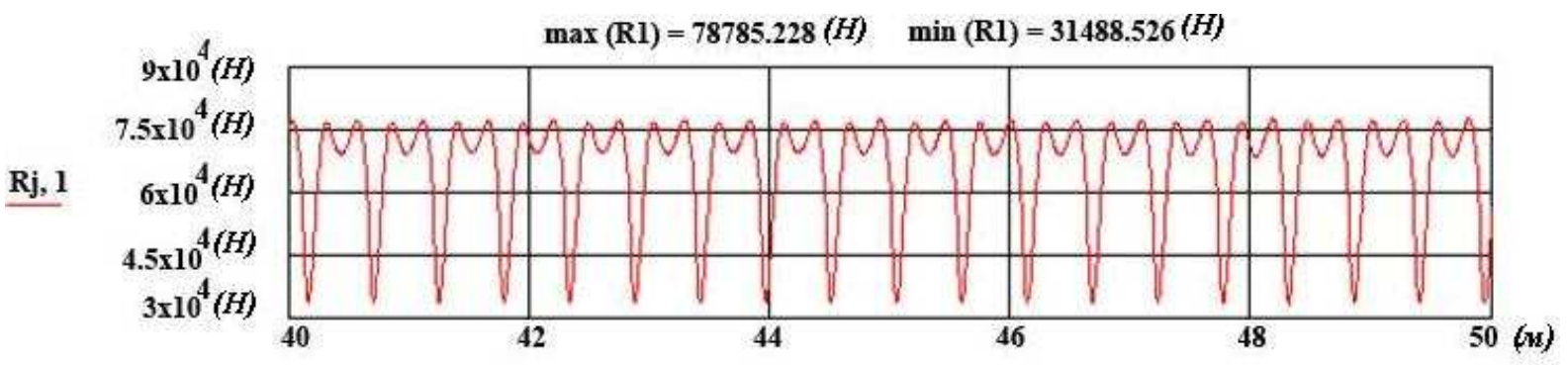

Рис. 2. Приклад графіка вертикальних сил при русі вагона типу 81-718 зі швидкістю 60 км/год в прямій ділянці

Слід зазначити, що при використанні розрахункової схеми рейки як балки на суцільній пружній основі в динамічних розрахунках сил взаємодії рухомого складу i колії у вертикальній площині, при русі вагона у прямій ділянці колії без нерівностей при сталому русі коефіцієнт динаміки та амплітудний коефіцієнт будуть дорівнювати 1. Між тим, в реальних умовах вертикальні сили безперервно змінюються і ці коефіцієнти відрізняються від одиниці суттєво. На рис. 2 наведено як приклад графіки змін вертикальних сил, які діють від колеса на рейку, що були отримані в результаті розрахунків для вагонів типу Еж3 і 81-718 зі швидкістю 60 км/год. Як вісь абсцис використана відстань, яку пройшли вагони, вісь ординат - сили дії в цьому прикладі, величини просторових жорсткостей рейкових опор були прийняті постійними.

Графіки показують, що на динамічні вертикальні сили впливають швидкість руху та жорсткість рейкових опор.

На рис. 3 наведені графіки залежності коефіцієнтів динаміки і амплітудних коефіцієнтів від швидкості руху. Графіки залежностей є показовими функціями, при цьому показник ступеня аргумента менше одиниці, хоч, орієнтуючись на загальне положення динаміки процесу взаємодії рухомого складу і колії, слід було очікувати інше значення. Вочевидь, на процеси динаміки має вплив не тільки швидкість руху, а й співвідношення жорсткостей ресорних комплектів вагонів і колії, параметри дисипації в цих підсистемах. При змінних швидкості руху від 10 до 80 км/год коефіцієнт динаміки змінюється від 1,01-1,02 до 1,0591,075. Значення амплітудних коефіцієнтів складають 1,06-1,15. Термін експлуатації колії вносить зміни коефіцієнтів динаміки і амплітудних коефіцієнтів на $15-20 \%$.

Введення в розрахунки нерівнопружності рейкових опор із застосуванням методу Монте-Карло має доволі суттєвий вплив на процеси взаємодії. Так, при швидкості руху 60 км/год зміна коефіцієнта нерівнопружності від 1,0-1,2 викликає збільшення коефіцієнтів динаміки від 1,15-1,205 (рис. 4).

При швидкостях руху, що реалізуються на коліях метрополітену, основний вплив на величину вертикальних динамічних сил мають ізольовані нерівності профілю довжиною до 6 м. На рис. 5 наведені графіки змін коефіцієнтів динаміки і амплітудних коефіцієнтів по вертикальних ізольованих нерівностях довжиною 2 та 4 м. Для встановлення впливу саме глибини нерівності на динаміку впливу рухомого складу на колію коефіцієнт нерівножорсткості рейкових опор був прийнятий рівним одиниці.

При швидкості руху 60 км/год по прямій ділянці колії 3 вертикальною ізольованою нерівністю 3 довжиною 2 або 4 м коефіцієнт динаміки в залежності від глибини нерівності досягає значень 1,123-1,129, амплітудний коефіцієнт 1,235-1,28. У випадку, коли в розрахунки вводиться нерівнопружність рейкових опор, коефіцієнти динаміки зростають на 12-20\%, амплітудні коефіцієнти - на 8-17\%. 


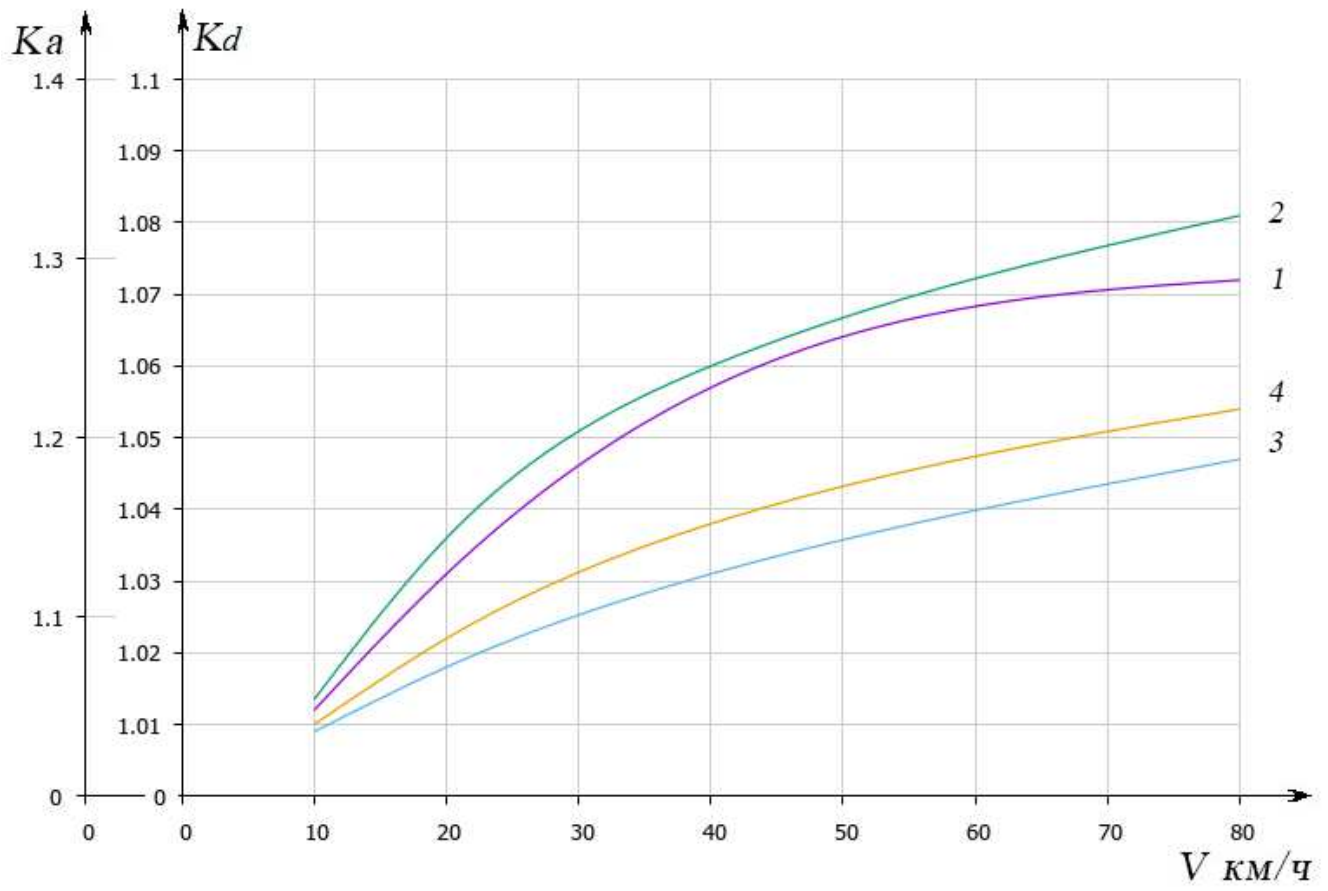

Рис. 3. Графік залежності коефіцієнтів динаміки і амплітудних коефіцієнтів від швидкості руху:

$$
\begin{array}{ll}
1-\mathrm{Kd} & \mathrm{t}_{\text {сл }}=0 \mathrm{pp} ; \\
2-\mathrm{Kd} & \mathrm{t}_{\text {сл }}=10 \mathrm{pp} ; \\
3-\mathrm{Ka} & \mathrm{t}_{\text {сл }}=0 \mathrm{pp} . ; \\
4-\mathrm{Ka} & \mathrm{t}_{\text {сл }}=10 \mathrm{pp} . \\
\text { де } \mathrm{t}_{\text {сл }}-\text { термін служби колії }
\end{array}
$$

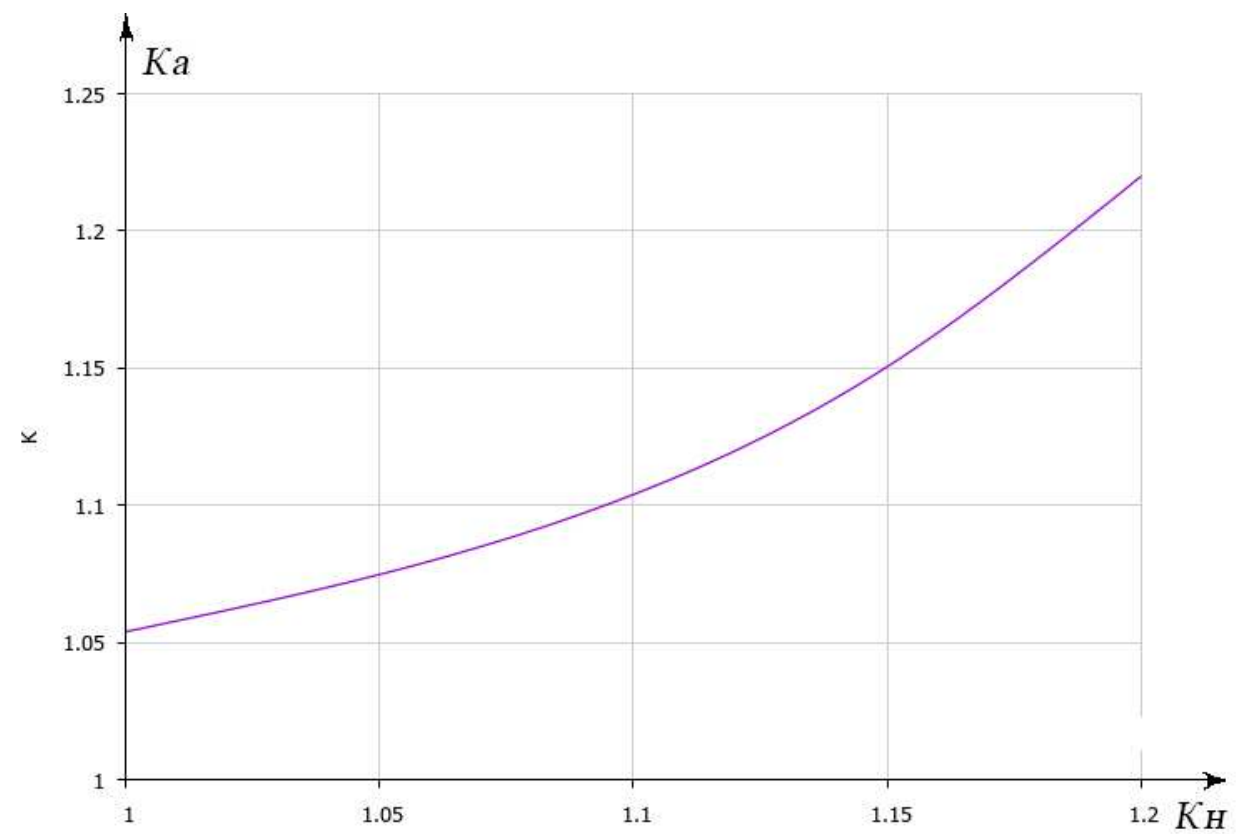

Рис. 4. Графік залежностей амплітудних коефіцієнтів величин нерівнопружності рейкових опор при русі по кривих ділянках зі швидкістю 60 км/год $K \mu$ та $K a=f$, кH, $\mathrm{V}=60$ км/год, $\mathrm{t}_{\mathrm{cл}}=0$ років 


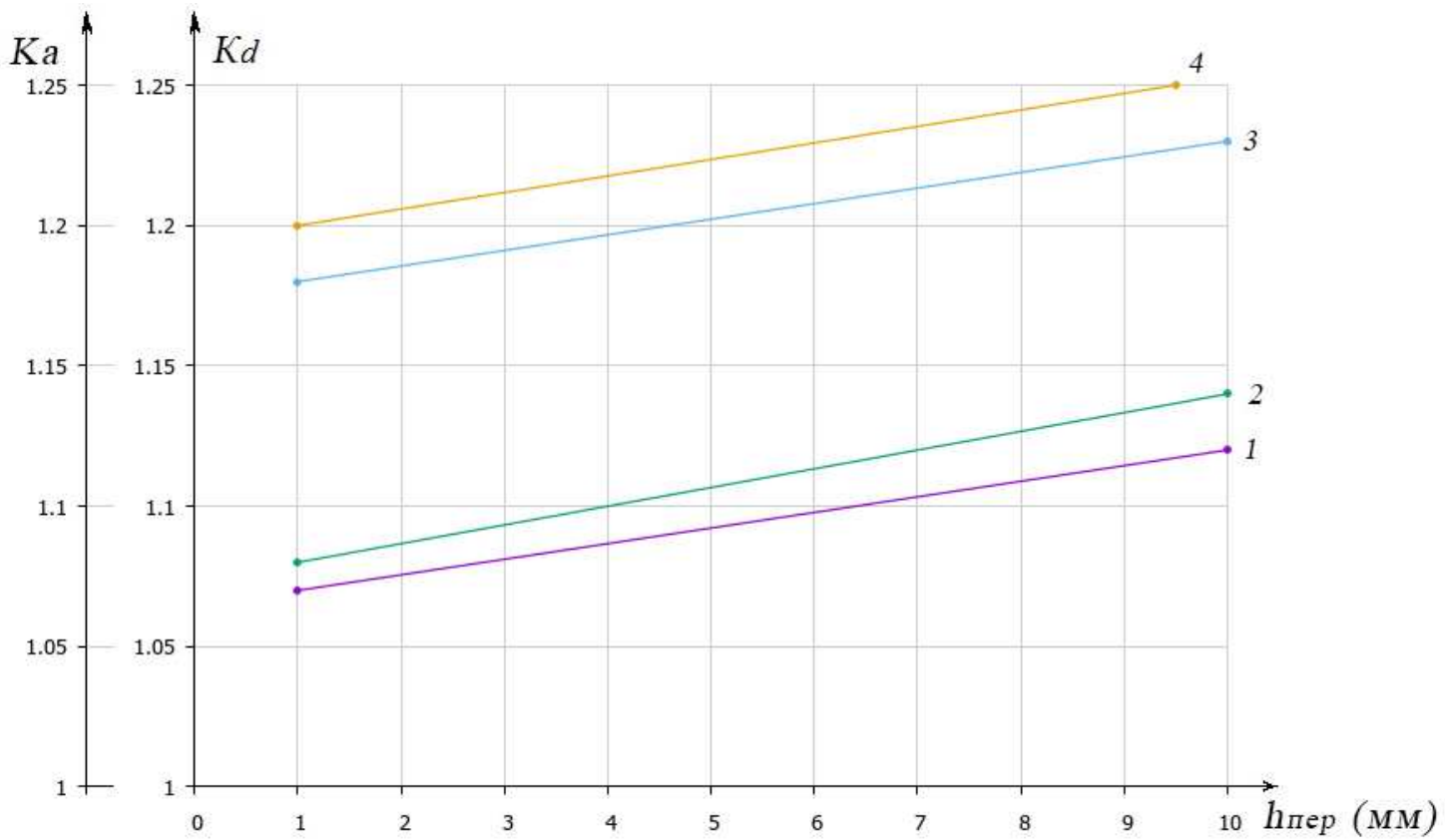

Рис. 5. Графік змін коефіцієнтів динаміки і амплітудних коефіцієнтів по вертикальних ізольованих нерівностях довжиною 2 та 4 м:

$$
\begin{array}{ll}
1-\mathrm{Kd} & 1_{\text {нер }}=4 \mathrm{м} ; \\
2-\mathrm{Kd} & 1_{\text {нер }}=2 \mathrm{M} ; \\
3-\mathrm{Ka} & 1_{\text {нер }}=4 \mathrm{м} ; \\
4-\mathrm{Ka} & 1_{\text {нер }}=2 \mathrm{M}, \\
\text { де } 1_{\text {нер }}-\text { довжина нерівності в колії }
\end{array}
$$

Таким чином, використання розрахункової схеми балки на багатьох пружно-дисипативних опорах дозволило встановити розрахунками вплив нерівнопружності підрейкової основи на величину вертикальних динамічних сил при русі вагонів метрополітену.

Максимальні розрахункові значення вертикальних динамічних сил наведені в таблиці.
Горизонтальні поперечні сили. На рис. 6 наведені графіки змін горизонтальних поперечних сил, які діють на колію від першої, по напрямку руху, колісної пари, при русі по ділянці колії, яка складається 3 прямої ділянки довжиною 50 м, перехідною кривої та кругової кривої 3 радіусом 400 м, підвищення зовнішньої рейки 120 мм.

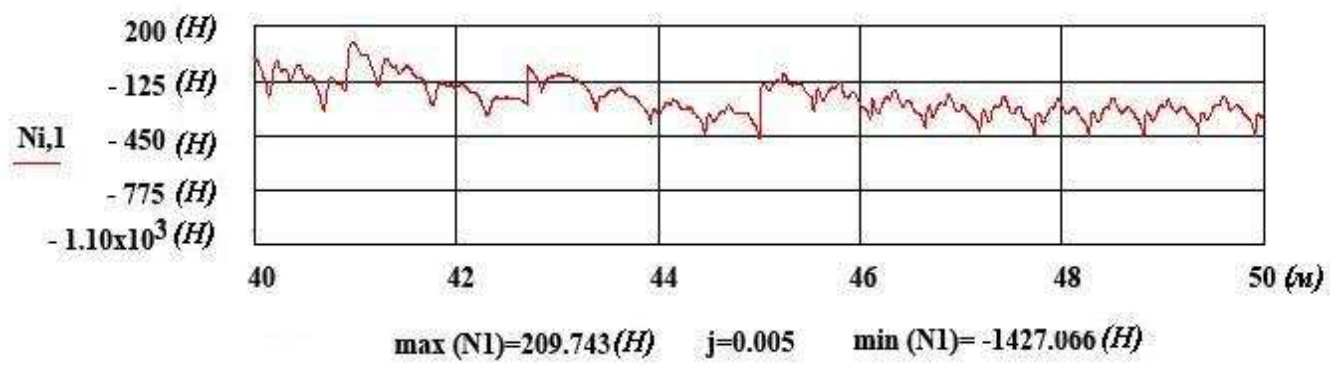

Рис. 6. Графік змін горизонтальних поперечних сил які діють на колію, $\quad \mathrm{N}=f ; \mathrm{V}=4,57$ м/с, 9,89 м/с

Швидкість руху в цьому розрахунку складала 80, 60 та 40 км/год. Максимальні значення горизонтальних поперечних сил складають від 4,57 до 9,89 кН. На рис. 7 наведені графіки залежностей горизонтальних поперечних сил від швидкості руху, які діють на колію в кругових кривих при відсутності нерівностей. Рівень горизонтальних поперечних сил при швидкостях руху, що реалізуються на коліях метрополітену, знаходиться в межах 0,29 - 11,183 кН. 


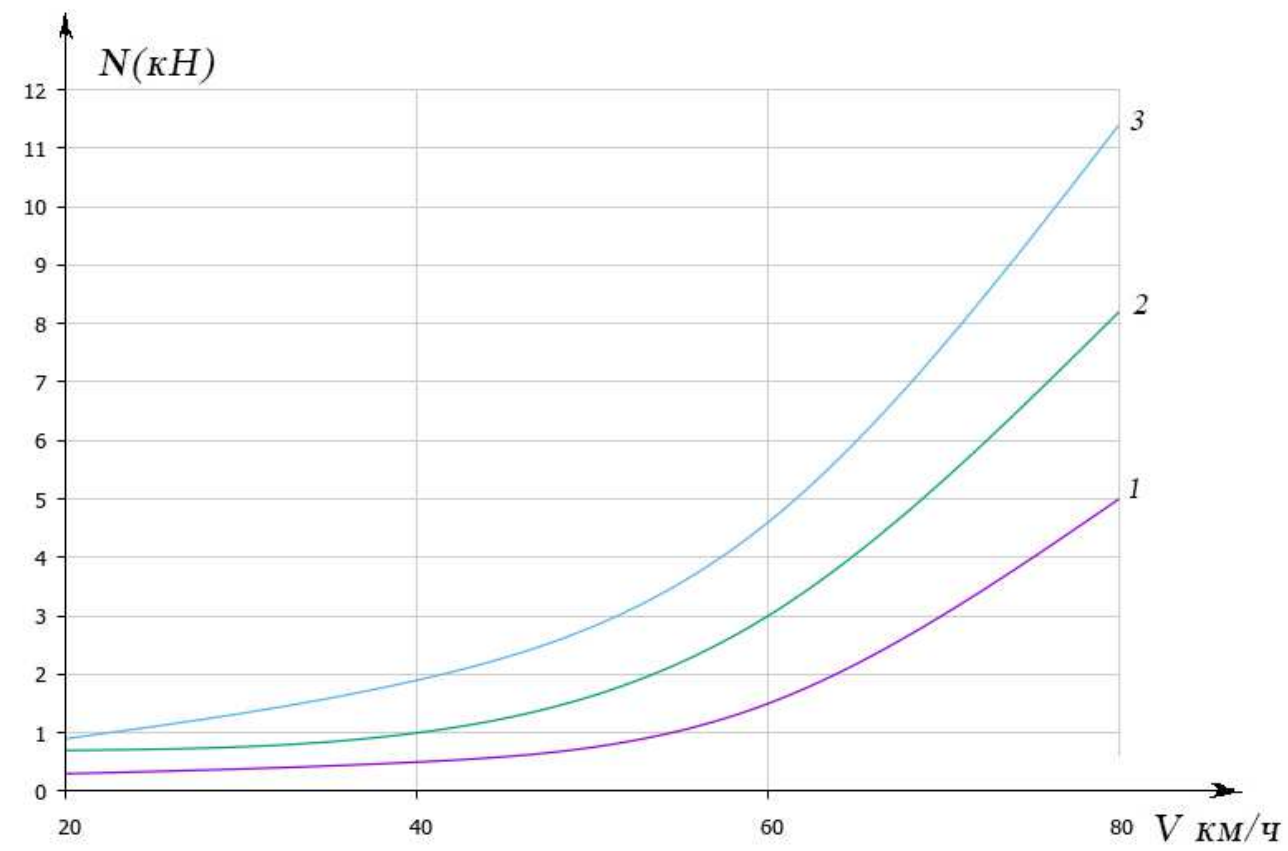

Рис. 7. Графік залежності горизонтальних поперечних сил від швидкості руху $\mathrm{N}=f \mathrm{~V}$ :

$$
\begin{aligned}
& 1-\mathrm{R}=400 \text { м } \mathrm{h}=120 \mathrm{мм} ; \\
& 2-\mathrm{R}=600 \mathrm{м} \mathrm{h}=120 \mathrm{мм} ; \\
& 3-\mathrm{R}=800 \mathrm{м} \mathrm{h}=120 \mathrm{мм}
\end{aligned}
$$

На рис. 8, як приклад, наведено графік змін горизонтальних поперечних сил однієї колісної пари при русі по ізольованих нерівностях плану довжиною 4 м. Залежності змін горизонтальних поперечних сил від амплітуди горизонтальних нерівностей довжиною 2 та 4 м наведено на рис. 9. Радіус кривої був прийнятий рівним 400 м. При змінах швидкості руху від 40 до 80 км/год горизонтальні поперечні сили досягають значень 12,5-14,8 кН в залежності від амплітуди і довжини нерівностей.

\section{Результати досліджень}

Розрахункові

значення

максимальних горизонтальних поперечних сил, які виникають в кривих ділянках колії, наведені в таблиці.

3 таблиці можна дослідити значення вертикальних та горизонтальних сил в залежності від радіуса кривих в ділянках. Таблиця $є$ ілюстративним висновком

\begin{tabular}{|c|c|c|c|c|c|c|c|c|}
\hline \multirow{3}{*}{ № } & \multirow{3}{*}{$\begin{array}{c}\text { Радіус, } \\
\text { м }\end{array}$} & \multirow{3}{*}{$\begin{array}{c}\text { Підвищення, } \\
\text { мм }\end{array}$} & \multirow{3}{*}{$\begin{array}{c}\text { Швидкість, } \\
\text { км/год }\end{array}$} & \multicolumn{4}{|c|}{ Діючі навантаження, Н } & \multirow{3}{*}{$\begin{array}{c}\text { Напруження, } \\
\text { МПа }\end{array}$} \\
\hline & & & & \multicolumn{2}{|c|}{ Вертикальні } & \multicolumn{2}{|c|}{ Горизонтальні } & \\
\hline & & & & $\min$ & $\max$ & $\min$ & $\max$ & \\
\hline 1 & пряма & 0 & 60 & 42087 & 75770 & & & 103.29 \\
\hline 2 & 400 & 120 & 60 & 42033 & 75866 & -1584 & -722.24 & 108.85 \\
\hline 3 & 600 & 120 & 60 & 42327 & 76219 & -6544.7 & -3151.2 & 123.79 \\
\hline 4 & 800 & 120 & 60 & 42414 & 76413 & -9105 & -4330.5 & 123.11 \\
\hline
\end{tabular}
проведених досліджень.

Рівень вертикальних і бокових сил, що діють на головку рейки від рухомого складу 

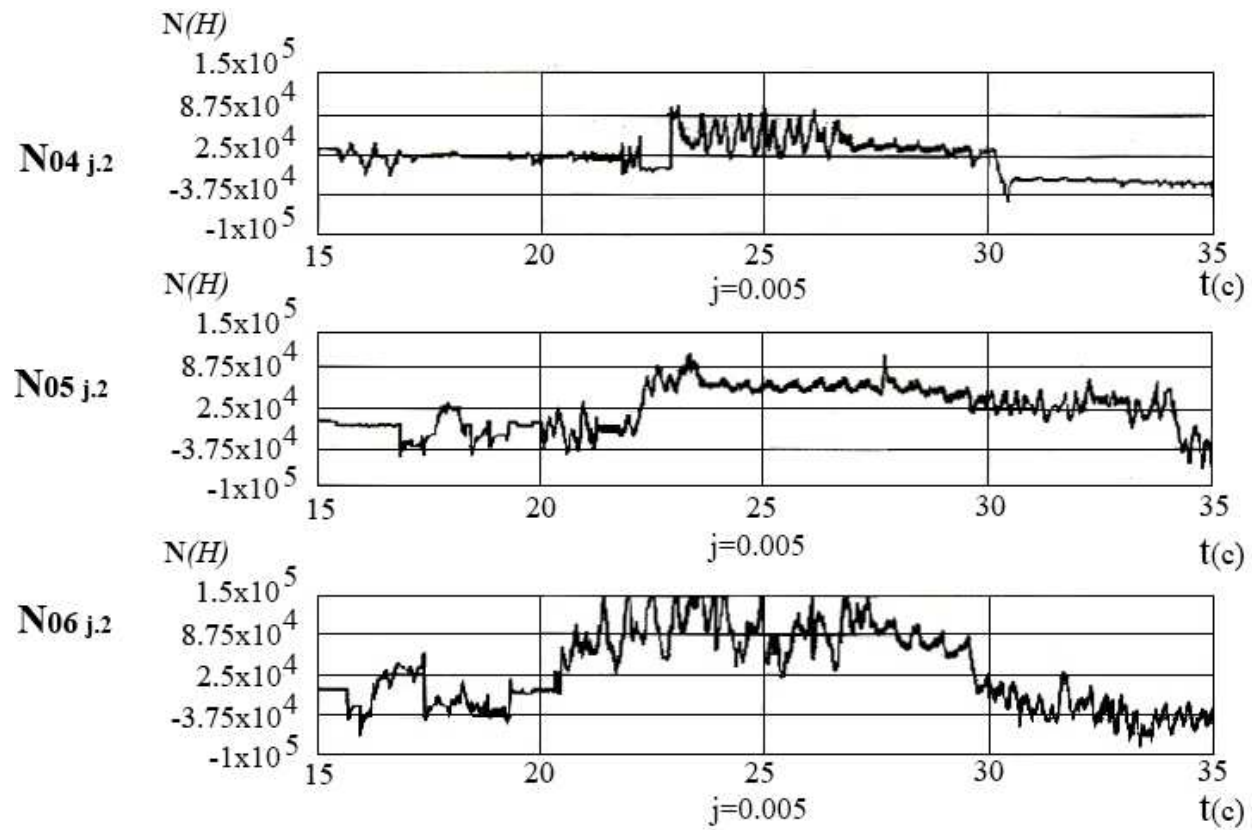

Рис. 8. Графіки горизонтальних поперечних сил при русі вагона Еж-3 по горизонтальній нерівності довжиною 4 м в прямій ділянці колії зі швидкістю 60 км/год:

$$
\begin{aligned}
& 1 \text { - стріла вигину - } 3 \text { мм; } \\
& 2 \text { - стріла вигину - } 6 \text { мм; } \\
& 3 \text { - стріла вигину - } 9 \text { мм }
\end{aligned}
$$

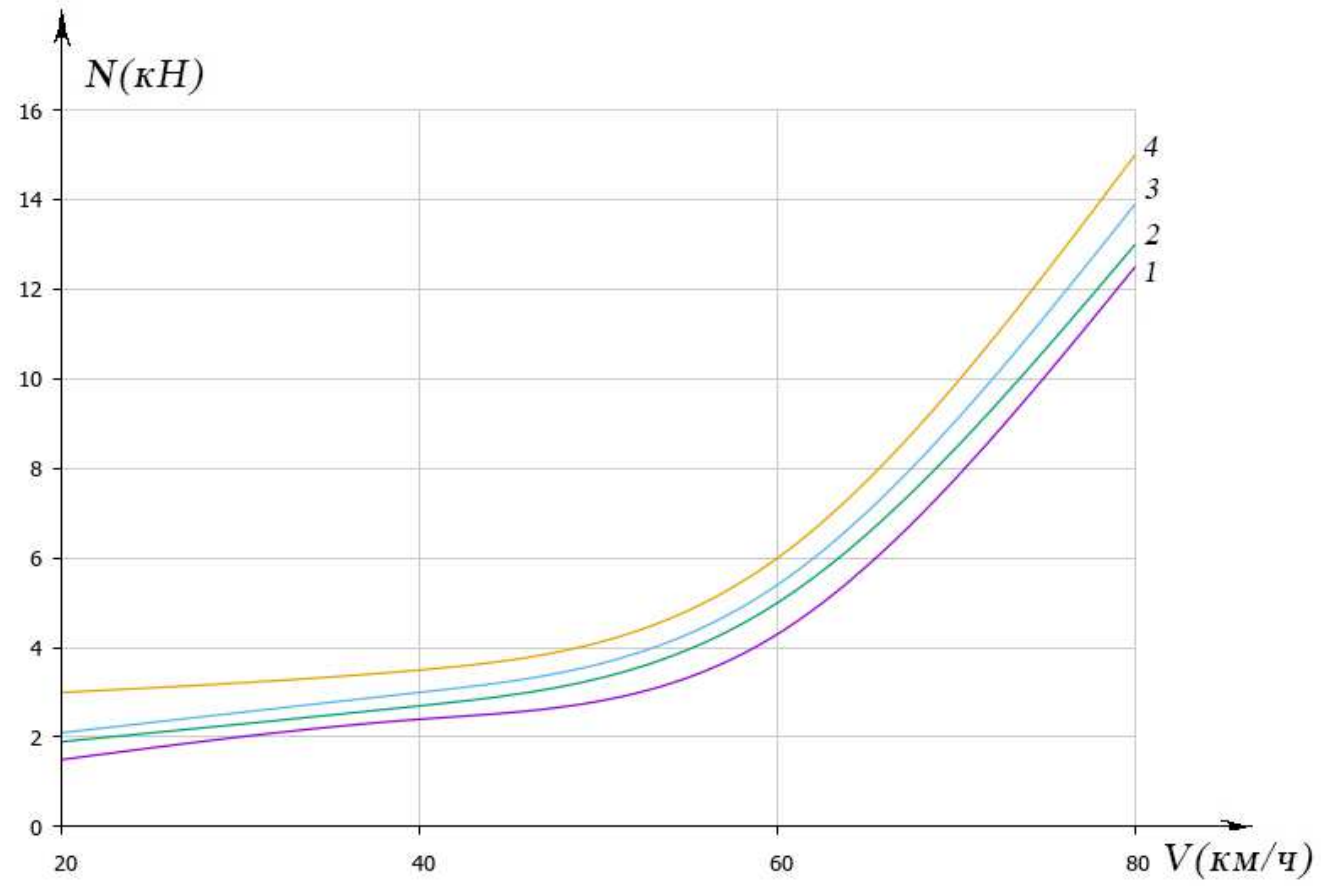

Рис. 9. Графіки залежностей горизонтальних поперечних сил при русі вагона Еж-3 з радіусом 400 м при наявності нерівностей:

1 - довжина нерівності 4 м, стріла вигину 6 мм;

2 - довжина нерівності 4 м, стріла вигину 9 мм;

3 - довжина нерівності 2 м, стріла вигину 6 мм;

4 - довжина нерівності 2 м, стріла вигину 4 мм 


\begin{abstract}
Висновки
1. Виконаний багатоваріантний розрахунок сил взаємодії вагонів метрополітену і колії з урахуванням особливостей Харківського метрополітену. Визначені вертикальні і горизонтальні поперечні сили при русі вагонів метро по прямих та кривих ділянках колії 3 різними швидкостями. Розглянуто вплив радіусів кривих вертикальних i горизонтальних нерівностей термінів експлуатації колії.

2. Отримані залежності коефіцієнтів динаміки i амплітудних коефіцієнтів вертикальних сил від швидкості руху вагонів метро по колії на дискретних пружно-дисипативних опорах. Встановлено, що дискретність спирання, нерівнопружність рейкових опор спричиняють виникнення динамічних сил, які перевищують статичне вертикальне навантаження в 1,2 разу. Вертикальні нерівності колії збільшують значення вертикальних динамічних сил в 1,08 1,15 разу.

3. Вперше було оцінено рівень горизонтальних поперечних сил в умовах метрополітену, встановлено вплив дискретності спирання нерівнопружності опор нерівностей коліі. Встановлено, що при швидкостях руху, які реалізуються на коліях метрополітену, можуть виникати горизонтальні поперечні сили, величина яких сягає 12,5-14,8 кН.
\end{abstract}

\section{Список використаних джерел}

1. Ангелейко, В. И. Вывод основных уравнений для расчета рельса в горизонтальной и вертикальной плоскостях [Текст]: монография / В.И. Ангелейко. - Харьков: ХИИТ, 1958.

2. Вериго, М. Ф. Определение динамического модуля пути [Текст] / М.Ф. Вериго // Техника железных дорог. - 1949. - № 12. - С. 23-24.

3. Коган, А. Я. Вертикальные динамические силы, действующие на путь [Текст] / А.Я. Коган // Труды ЦИИТ МПС. - М.: Транспорт, 1969. - 206 с.

4. Даніленко, Е. І. Правила розрахунків залізничної колії на міцність і стійкість. ЦП-0117 [Текст]: затв. наказом Укрзалізниці від 13.12.2004 р. №960-Ц3 / М-во транспорту та зв'язку України. Держадміністрація залізничного транспорту України. Укрзалізниця / Е.І. Даніленко, В.В. Рибкін. - К., 2006. - 168 с.

5. Ершков, О. П. Исследование жесткости железнодорожного пути и ее влияние на работу рельсов в кривых участках [Текст] / О. П.Ершков // Труды ЦНИИ МПС. - М.: Трансжелдориздат, 1964. - Вып. 264. - С. 39-48.

6. Шахунянц, Г. М. Некоторые вопросы исследования работы резиновых прокладок повышенной упругости для пути с железобетонными шпалами [Текст] / Г.М. Шахунянц, А.А. Демидов. - М.: МИИТ, 1971. Вып. 354. - С. 24-32.
7. Даренский, А. Н. Результаты исследований численными методами вертикальных воздействий на путь специальных и специализированных вагонов промышленного транспорта [Текст] / А. Н. Даренский // Зб. наук. праць ДонНИИЖТ. - 2010. № 24. - С. 168-179.

8. Даренский, А.Н. Особенности взаимодействия пути и подвижного состава промышленного транспорта в кривых малого радиуса [Текст] / А.Н. Даренский // ІКСЗТ. - 2011. - №1. - С. 25-30.

9. J Otero, J Martínez, M A de los Santos and S Cardona (2011). A mathematical model to study railway track dynamics for the prediction of vibration levels generated by rail vehicles.Proceedings of the Institution of Mechanical Engineers, Part F: Journal of Rail and Rapid Transit, 226, 62-71.

10. Grassie, S. L., Gregory, R. W., \& Johnson, K. L. (1982). The dynamic response of railway track to high frequency lateral excitation. Journal of Mechanical Engineering Science, 24(2), 91-95.

11. Suarez, B., Felez, J., Antonio Lozano, J., \& Rodriguez, P. (2013). Influence of the track quality and of the properties of the wheel-rail rolling contact on vehicle dynamics. Vehicle System Dynamics, 51(2), 301-320.

12. Карпущенко, Н. И. Расчет упругих элементов промежуточных рельсовых скреплений [Текст]: монография / Н.И. Карпущенко // Труды НИИЖТ. - 1972. - №135. - С. 41-48.

13. Йосифович, Р. М. Наукове обгрунтування i практичне вирішення проблеми підвищення експлуатаційного ресурсу рейок київського метрополітену в 2013-2016 рр. [Текст]: автореф. дис... канд. техн. наук: 05.22.06 / Р.М. Йосифович. - К: ДЕТУТ, 2016. - 26 с.

14. Даніленко, Е. І. Дослідження впливу динамічних колісних навантажень, вантажонапруженості i швидкостей руху поїздів на міцність, стійкість і строки служби рейок, скріплень на інших елементів ВБК [Текст] / Е.І. Даніленко, Р.М. Йосифович, О.А. Олійник, О.О. Сорока // $3 б$. наук. праць ДЕТУТ. Сер. Транспортні системи і технології. - К.: ДЕТУТ, 2013. - Вип. 22. - С. 9-19.

15. Твердомед, В. М. Огляд технічних характеристик конструкцій верхньої будови залізничної колії та їхніх умов експлуатації на лініях Київського метрополітену [Текст] / В.М. Твердомед, Р.М. Йосифович // Зб. наук. праць ДЕТУТ. Сер. Транспортні системи і технології. - К.: ДЕТУТ, 2014. - Вип. 24. - С. 70-80.

16. Агарков, О. В. Визначення контактних напружень в рейках типу P50, які експлуатуються в метрополітені [Текст] / О.В. Агарков, Р.М. Йосифович // Наука та прогрес транспорту: зб. наук. праць. - Дніпропетровськ: ДНУЗТ, 2015. №4 (58). - С. 71-86. 
17. Даренський, О. М., Математична модель системи «екіпаж-колія» для умов метрополітену [Текст] / О.М. Даренський, А.С. Малішевська // Інформаційно-керуючі системи на залізничному транспорті. - 2016. - Вип. 6. - С. 56-61.

18. Курган, М. Б. Визначення допустимої швидкості руху поїздів з примусовим нахилом кузовів вагонів в кривих ділянках колії [Текст] / М.Б. Курган, Д.М. Курган, В.І. Харлан // Вісник Дніпропетровського національного університету залізничного транспорту імені академіка В. Лазаряна. - 2006. - № 12. - С. 47-52.

\begin{abstract}
А.Н. Даренский, А.С. Малишевская. Использование математической модели динамической системы «экипаж-путь» для исследований сил взаимодействия подвижного состава и пути метрополитенов. В статье проведено определение вертикальных и горизонтальных поперечных динамических сил, которые возникают при взаимодействии подвижного состава и путей метрополитена. Определение осуществлялось на основе предыдущих исследований, в результате которых были разработаны модели и методы расчетов таких сил. В статье приведена реализация математических моделей $\mathrm{c}$ помощью программы Matcad. Новизна подхода к изучению взаимодействия подвижного состава и путей метрополитена заключается в учете и оценке уровня именно горизонтальных поперечных сил.

$\begin{array}{llll}\text { Ключевые } & \text { слова: } & \text { вертикальные } & \text { силы, } \\ \text { горизонтальные } & \text { поперечные силы, } & \text { путь, }\end{array}$ неравноупругость рельсовых опор, коэффициент динамики, вертикальная изолированная неровность.
\end{abstract}

importance of nonlinear forces guiding the light rail rigidity yarn at its bending, twisting and energy dissipation in the horizontal plane. Included impact tilt rails and super elevation in curves.

The article shows the implementation of mathematical models using Matcad. The novelty of the approach studies the interaction of rolling stock and metro lines is the account of and evaluation of exactly horizontal transverse forces.

Keywords: Vertical forces, horizontal transverse forces, way, unequally elasticity rail supports, dynamics factor, isolated vertical unevenness.

Надійила 01.02.2017 p.

Даренський Олександр Миколайович, доктор технічних наук, професор, завідувач кафедри колія та колійне господарство Украӥнського державного університету залізничного транспорту, Харків, Україна.E-mail:_ppx_xiit@kart.edu.ua

Малішевська Аліна Сергіївна, аспірант, кафедра колія та колійне господарство, Украӥнський державний університет залізничного транспорту, Харків, Україна. E-mail: kttolik@yandex.иа

Darenskiy Alexander, PhD, Dr. Sc. Professor, Head of Department of track and track facilities of Ukrainian State University of Railway Transport, Kharkiv, Ukraine. Email:ppx_xiit@kart.edu.ua

Malishevskaya Alina, postgraduate, department of track and track facilities, Ukrainian State University of Railway Transport, Kharkiv, Ukraine. E-mail: kttolik@yandex.ua
A.N. Darenskiy, A.S.Malishevskaya. Using mathematical models of dynamic systems "crew-track" powers to study the interaction of rolling stock and tracks underground. Most studies that have examined the interaction track and rolling stock, defined vertical or horizontal lateral forces acting on the track by driving crews in straight and curved sections of track.

However, in terms of metro (small radius curves, especially special rolling stock, especially the modes of rolling stock) should be considered significant nonlinearity dependence, including nonlinearity discontinuous type. As for nonlinear systems superposition principle cannot be applied, research carried out on non-linear spatial model. This publication held definition of vertical and horizontal transverse dynamic forces arising from the interaction of rolling stock and tracks underground. Determination was carried out on the basis of previous studies in which developed models and methods of calculation of such forces. Determined the conditions for the emergence and 